\title{
Framing the Future of National Parks
}

\author{
Thomas Widlok and Ndapewa Fenny Nakanyete
}

Contrary to the colonial and developmental image that Africa is 'lagging behind' and needs to 'catch up' with Europe, the more recent position holds that Africa is 'the future' in the sense that many ideas and practices that characterize Africa today are foreshadowing processes of a global future at large (see Comaroff and Comaroff 2011). In many instances, the notion of a future 'Africanization' of Europe (see Mbembe 2017) highlights problematic developments such as precarious labour relations and the categorization of some members of society as 'superfluous'. But what are domains in which African developments may foreshadow positive changes for the future of the north and the globe at large? When searching for such domains the strength and growth of nature conservation in Africa stand out as a promising candidate.

In this chapter, we therefore compare a case from the south, Namibia, which has a very strong track record of nature conservation, with a case from the north, Germany, which appears to be a relative newcomer, 'catching up' only recently by establishing national parks for the first time across the country. ${ }^{1}$ In Namibia, the conversion of land into protected areas has reached a larger scale than ever before and it does so against a long history of national parks. In Germany, by contrast, and despite earlier attempts to protect small areas, national parks are latecomers, aspiring to a status that parks in Africa already possess. We shall not only compare formal processes of institutionalizing nature conservation but also more generally investigate the temporal frames that are created and employed in the two contexts.

To what extent are national parks projects that are setting the frame for conservation in the future and to what extent are they, in turn, being informed by particular ways of framing time and the future? By temporal framings, we mean ways of conceiving and dealing with the land with regards to the time

1 We realize that this comparison is explorative rather than conclusive and we seek to broaden the scope in future collaborative work which has been delayed due to the coronavirus pandemic. The choice of the two countries is, however, not arbitrary since the two countries are at different ends of the spectrum in terms of the early establishment of national parks (Namibia) and the very recent establishment of such parks (in Germany). Ultimately, we would like to include other, neighbouring countries in the comparison and more cases within each country to go beyond the minimal comparison of two cases from each country.

(C) THOMAS WIDLOK AND NDAPEWA FENNY NAKANYETE, 2022 | DOI:10.1163/9789004471641_012 
dimension, for example as 'coming from an ancient past', 'eternal', or as 'for the future' and so forth. Such frames inform both, discursive practices and other practices such as converting the land and various forms of living off the land. Concerning institutions such as national parks, we find some of the temporal framings being made explicit in brochures, monuments, signboards or documents. But at least in part, those framings are implicit in practices, for instance in rules for visiting, the establishment of development zones, and the adoption of a 'project' approach (see below). Arguably, the more implicit a frame, the more effectively it influences people's views and actions since implicit frames operate out of awareness and are typically not subject to debate and criticism.

To say that Namibia's national parks are old and established while Germany's are recent and developing glosses over many particularities of the various areas in question. Moreover, the Namibian parks were in many cases creations of German or South African colonialism, serving the interests of colonial regimes and not those of the local population. The park boundaries were also redrawn for strategic and political reasons (de la Bat 1982: 20). The Namibian national parks under consideration here were established as protected areas with several functions: the Etosha National Park was partly used to police the Haillom San in the area (and migrating labourers from the north of the country). Several parks in northern Namibia (including Etosha and the precursors of what is now the Bwabwata National Park) were used militarily to protect the European settlement areas further south during the war of independence (see Boden 2009; Dieckmann 2007; Jones and Dieckmann 2014). In colonial times therefore, various motivations fuelled the establishment of national parks and it was only after independence in 1990 that Namibia incorporated effective environmental protection laws into its new constitution for the management of national parks and other protected areas. This gave the country international recognition as one of the world's first states to include the protection of the environment in its constitution, with Article 95 (I) promoting conservation of the ecosystem, its biodiversity, and the sustainable use of natural resources for the benefit of its both current and future citizens. ${ }^{2}$

Today, Namibia's state-run protected areas, including national parks, cover 13,000 square kilometres, which is equivalent to 20 per cent of the country's territory (see NACSO 2015). When all non-state-run areas (including

2 Article 95 of the Constitution of the Republic of Namibia is promoting "the welfare of the people" through various measures including the "maintenance of ecosystems, essential ecological processes and biological diversity of Namibia and utilization of living natural resources on a sustainable basis for the benefit of all Namibians, both present and future" (https://laws.parliament.na/namibian-constitution/). 
conservancies and community forests) are included, about half the country has some sort of protection status. The rights of possession to these areas vary. Whereas national parks belong to the state and are run by the Ministry of Environment and Tourism (known as Ministry of Environment, Forestry and Tourism since 2020), conservancies and community forests are co-managed by communities, more recently established under state administration, and they include communal and (to a lesser degree) privately-owned land.

Germany's national parks were all established fairly recently as a consequence of the national biodiversity strategy to have at least 5 per cent of forested land declared protected wilderness areas by the year 2020. Therefore, every state in the Federal Republic sought to have a fixed proportion of its conservation areas set aside as national parks subject to international regulations. The Eifel National Park was established in 2004 and the Black Forest National Park as late as 2014. Moreover, these are looked upon as national parks 'in the making' because they do not, as yet, have the right proportion of undisturbed core areas that international standards require. While Namibia's parks are institutionally old but have undergone recent turns in conservation, Germany's may be institutionally new yet nonetheless incorporate old practices. Germany's state forestry departments were the first to coin the now globally used notion of 'sustainability', albeit mainly in an attempt to make themselves central and indispensable (see Radkau 1996). Their way of setting the 'undisturbed high forest' as a standard for conservation was to a large extent a tool for marginalizing and undermining the communal practices of forest-dwelling peasants and a continuation of the rights of the landed gentry in the hands of the nationstate (Radkau 1996: 65-6).

Thus, the official history of establishing national parks and other conservation areas is a complex story that cannot be read as a simple developmental sequence in either of the two cases. This raises the question of what temporal frames may be found under the surface picture presented in glossy brochures.

\section{$2 \quad$ Recognizing Temporal Framings in National Parks}

Arguably, the future is determined not only by the power of agents (for example the power of the state to create laws or the power of NGOs to mobilize people) but also and more fundamentally by the frames in which the future is conceived, the framing that constitutes the playing field of the political agents, so to speak. However, the recognition of time frames cannot easily be elicited by consulting the dominant discourse. The most effective time frames are those that have become so natural to agents that they are no longer 
recognized since they are out-of-awareness 'framings'. For instance, a surface discourse of conservation 'for future generations' or 'for present and future generations' (see Photo 1) is commonly found in the establishment of all national parks (and other protected areas). However, underlying this focus on the future (and present), there is also a largely implicit framing of timelessness that is found in the rhetoric of biodiversity protection more generally. This underlying frame of 'timelessness' is, analytically, just a specific temporal frame, namely one that operates with culturally specific notions of 'eternity'. Euro-American national parks are fuelled by a strong sense of 'the sublime', of a particular experience of nature that often carries religious undertones with the emphasis on 'that which lasts' as opposed to the hectic and changing times of modernity (Cronon 1996). Today, this tendency is manifested in German national parks in several ways.

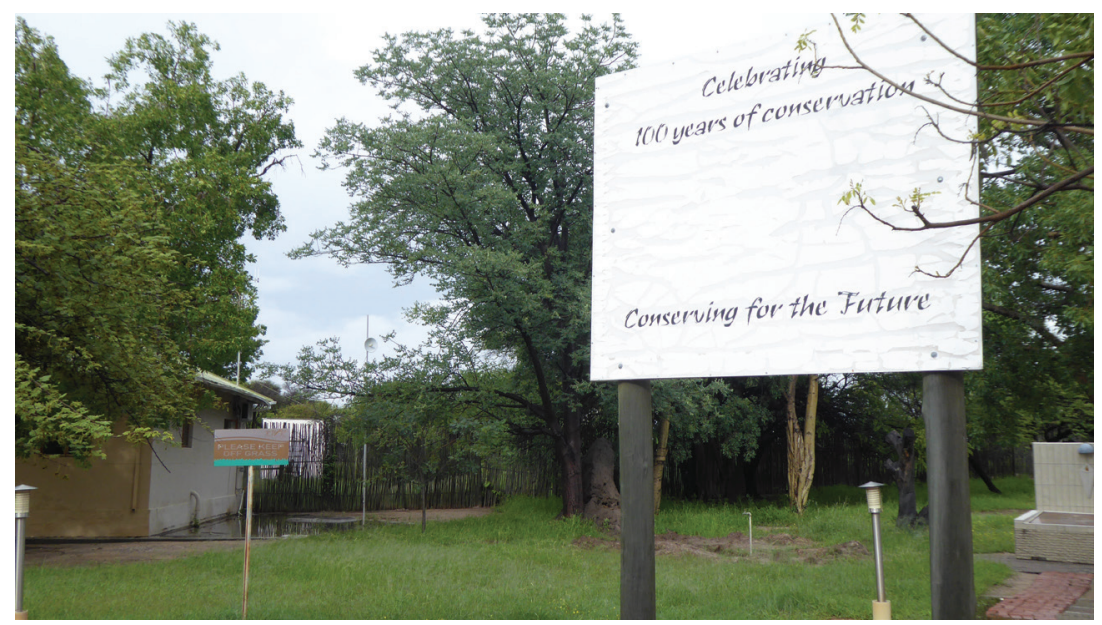

FIGURE 1 Sign at Namutoni, Etosha national park THOMAS WIDLOK

The main Christian churches in the Eifel have developed a 'creation path' within the park itself, and the Black Forest National Park also has a regular programme of church-based events in which the 'breath of eternity' (Atem der Ewigkeit) can be felt. ${ }^{3}$ For the less religiously-oriented visitor, pieces of paper containing quotations from well-known poets such as Hermann Hesse and Johann Wolfgang von Goethe are available from the park's centre. These

3 See https://kirche-tourismus-bw.de/html/content/kirche_im_nationalpark_schwarzwald. html [20 October 2020]. 


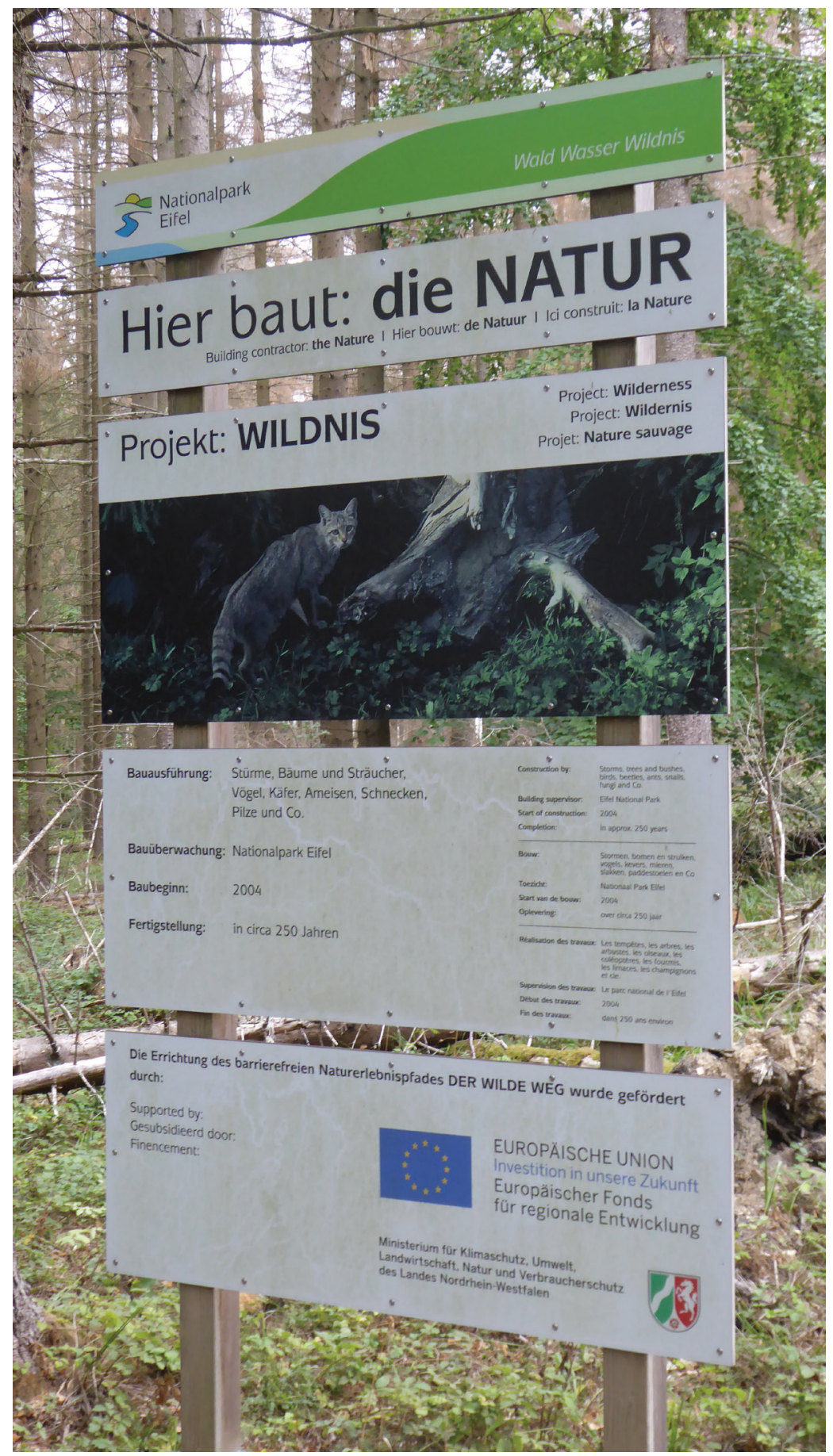

FIGURE 2 Sign at Eifel national park THOMAS WIDLOK 
quotations invariably invoke the timelessness of nature ${ }^{4}$ and provide an intellectual and emotional dimension for those visiting the park. The Eifel National Park presents itself to the public as a 'building site' for wilderness, with nature as the builder and an approximate 'finish' date in 25o years' time (see Photo 2). This relates to one of the key slogans used by national parks in Germany, namely 'Urwälder von morgen' (Primordial/timeless forests of tomorrow). Parks also occasionally incorporate pilgrimage sites (or parts of pilgrim ways), places of mystical encounters (such as the Mummelsee in the Black Forest), a way of the cross, summit crosses, wayside chapels and so forth. ${ }^{5}$ That no national park comes with a shelf-life underlines the sense of awe and eternity they provoke. There is no date envisaged when the park would be handed over to a future generation, or a point in time when it would be degazetted because its function had been fulfilled. While they may have a distinct past, the parks are typically imagined to stretch into an endless future of 'coming generations'.

One effect of this rhetoric of timelessness is that neither the future of the park nor the authority of the state to guarantee that future is easily challenged. The cumulative interests of endless future generations must, by definition, outweigh any disadvantages or conflicting interests that any particular stakeholder may have today or any grievances that may be brought in from the past. The aspirations of a (largely unrealized) future outweigh the particulars of the concrete past and present, and such a frame is therefore biased towards an unspecific eternal future. We argue that whatever steps towards the future development of the protected area may be undertaken in both Germany and Namibia, they all operate against the backdrop of an 'eternity'. When parks are portrayed as harking back to a 'time immemorial' before human occupation and are envisaged as cathedrals of the future, they effectively eclipse the interests (and conflicts of interests) in the here and now. Moreover, their detached status is claimed and reproduced by the managing state authorities - which is mutually reinforcing since the nation-state, too, presents itself as an eternal entity above and aloof from the particularist interests of ethnic/social groups or individuals.

In Namibia, the state authorities who manage the national parks recognize and justify temporal framing through independence and nationalism, which

4 For instance, one quotation by Goethe reads, "Wohl ist alles in der Natur Wechsel, aber hinter dem Wechselnden ruht ein Ewiges" ("Everything in nature changes, but behind the change there is something eternal."

5 It is noteworthy that national parks in Namibia include colonial graves, marked as sites for visitors, but so far disregard pre-colonial religious sites. Pre-colonial graves in the park are currently out of bounds, cannot be visited or ritually attended to, which mutes the voice of those connected to the land through these sites. 
are then mobilized in decisions about the present while assessing the impact for the country's future. The concept of national parks as a natural heritage asset is often declared to be for the benefit of present and future Namibian generations at large. As a consequence, temporal frameworks involving conflicts of interest between the nation-state and particular interests of ethnic groups become difficult to include. The Etosha National Park as an 'ancestral home' for the Haillom San holds significance as a place of origin and identity (see Suzman 2001), but the dispossession of the San due to the establishment of the Etosha National Park as an eternal national good makes it difficult for the San to realize spiritual values and connections in their present-day life or for the future of their children. The same holds for other local attachments to areas subsumed under national parks in the country.

In a current land claim court case, the Namibian state, as the main defendant, concludes that there is no recognized method of estimating the 'intrinsic value' of Etosha National Park. The value is not quantified because it includes "natural capital; conservation value; symbolic value; emotional value, ecosystem services; positive impact on the value of adjacent farms, and tourism" and it would have also to include the unrealized 'option value', that is "the option to use resources in the future ... often associated with the diversity of protected areas, the future potential value of which is unknown." ${ }^{6}$ In other words, Etosha has 'invaluable' value for future state revenue as a unique international tourist destination. Sharing 'eternity benefits' among particular 'stakeholder' groups is therefore problematic, maybe even more problematic than distributing the 'eternity costs' of industrially destroyed land, for instance in Europe's coal extraction regions or nuclear wastelands elsewhere.

\section{3}

\section{Standardization of Temporal Frames}

While the 'eternity' temporal framing may be more or less diffuse and underspecified, there are also temporal framings that are more precise and subject to international standardization. The international standards of national park management, for example, are geared towards very specific timelines. They largely disregard any changes to the status of a stretch of land (or water) in the past but are very specific for instance with regard to the size of a park and the proportion of its 'untouched' core zone in relation to buffer or mixed-use zones (see Wild Europe 2013). The zoning of protected areas is itself not only a

6 Affidavit of Minister Pohamba Shifeta (pp. 682-9) in the court case of J. Tsumib et al. against the Government of the Republic of Namibia, 14 July 2016 (Case A206/15), emphasis added. 
spatial device but also a temporal one in that it specifies not only what human activity should be allowed in each zone but also when (up to when, or how often) this should take place.

In Namibia, for instance, some national parks consist of zones demarcated for large and exclusive nature conservation, with other zones including confined settlement for (present) indigenous communities, who live under restrictions concerning where they can settle and what livelihood activities they can pursue. This zoning corresponds to the strategic goals of increasing protected areas while also increasing subsistence opportunities for the local population. Such restrictions are usually not (re)negotiated over time despite population growth and land degradation in the residential zones. This significantly affects the food security and livelihood strategies of resident communities living in or near national parks (see Paksi and Pyhälä 2018).

Meanwhile, national parks in Germany are gazetted in such a way as to prevent anyone permanently settling in the area and they have a target plan for the future that dismantles settlements, paths and other infrastructure. The parks are not considered 'finished' and 'ready' when they are established, but are seen as 'projects', states of wilderness projected into the future to reach international recognition over a set period of time. Park management is then geared towards not losing that recognition by complying with the development targets that international standards require. In its simplest but most effective sense, this standardization is about setting 'deadlines' and being committed to them. These are deadlines after which no more human interference is supposed to take place; they are there to eliminate invasive species such as the Douglas fir, which was imported into the Eifel from North America, and to provide a timetable for the (re)introduction of native species, for instance allowing wolves to return to Germany.

Wildlife management, in Germany and Namibia, involves quotas, including temporal framing to specify how many animals can be shot over a certain period, typically a calendar year. The annualization implicated in taxation and business plans operating within financial years organizes time in very specific ways. Although parks may technically not be considered commercial land, their time frames are thereby very much aligned with those of commerce. In Bwabwata National Park in Namibia, for example, wildlife management through trophy hunting is said to provide socio-economic benefits to local communities through hunting revenue, game meat distribution and employment as trackers, especially for the local Khwe San. In return, indigenous residents are expected to comply with the standardized sustainable management of natural resources for generations to come, while their traditional livelihood 
strategies as custodians of the environment, which differ from the scientific notion of conservation, remain constricted or prohibited. ${ }^{7}$

In this sense, national park management is above all a form of management, a standardized tool for setting goals, translating goals into targets and measures, and evaluating the results in a predefined temporal frame. Thus, despite the underlying imagery of eternity and 'future generations', management plans by definition apply standardized timeframes that emerge from the logic of economic planning, corporate profiles, 'production' targets and so forth. Although national parks are explicitly excluded from the economy of markets in many ways (for instance, the land cannot be sold and is considered a national asset), they still partake in the temporal logic of corporations. Land use practices are translated into 'management', which inherently organizes ideas, practices, humans and non-humans into a series of 'outcomes' that can be calculated and scheduled (see Abbott 2016). Again, this framing appears to many so 'natural' and clandestine that it is not recognized as a rather specific cultural practice of temporal framing. The frames may only become visible when stakeholders fail to comply with this implicit management logic, as in the case of indigenous minorities (see Sapignoli 2018; Zips-Mairitsch 2013).

As we have shown above there are temporal framings that re-emerge such as the assumed eternity of nature across parks and countries. There are also temporal framings that are diversified and contested even within countries and regarding individual parks.

Government, international agents and NGOs often accept (sometimes reluctantly) that there may be conflicting projects present with regard to a particular piece of land that is declared a protected area, but at the same time, they try to set down the (temporal) conditions for getting involved. Correspondingly, associations and consultation bodies are established when conservancies, community forests or national parks are being created. There may

7 Khwe representatives from Bwabwata National Park have recently visited the Eifel National Park, and a good number of national park staff in Germany have some experience of national parks outside Europe. Nevertheless, the exchange between 'traditional ecological knowledge' and park management remains very limited. https://www.nationalpark-eifel.de/de/nationt alpark-erleben/aktuelles/artikel-detailseite/Besuch-aus-Namibia-Traditionelles-oekologisches-Wissen-im-Austausch-3172R/. 
be fundamental differences in the way these stakeholders frame the park in its temporality, ranging from short-term economic gain to transgenerational interests and the notion of a permanent shared heritage. It seems, however, that in Namibia and in Germany, these fundamental differences are rarely discussed directly but remain largely implicit. Stakeholders can voice their particular interests but they have to be prepared to channel them through the 'technical' procedures of hearings, points of public inspection and regular consultations or - when conflicts intensify - in terms of court hearings, lawsuits and other forms of legal action at various levels. All these technical procedures have their specific time regimes. ${ }^{8}$

Court cases, such as the one currently underway in Namibia, in which both the ownership status of Etosha National Park and the distribution of benefits from its resources are at stake, are notorious for taking a long time, often beyond the lives of individual defendants. It has been more than sixty years since the Haillom San of Etosha lost their ancestral land rights through eviction, but their first court case to reclaim these rights only opened in 2015 (see Menges 2015). There have since been delays and dismissals of the case because of political factors involving both the government and the affected community; the latest appeal has (at the time of writing) still not been heard. Efforts to self-organize and mobilize the community into demonstrating the urgency of the recognition of their land rights in the park have been going on since 1996. The government's refusal to approve the chief that the community had elected as its representative in the Council of Traditional Leaders, prompted some Haillom San to organize a protest at the gates of the Etosha National Park to draw attention to their claim for ancestral land. This resulted in the arrest and imprisonment of 73 community members. However, they were later granted bail and the charges were eventually dropped (see Dieckmann 2007). Despite subsequent attempts by various civil society agents and international organizations to gain recognition for the San way of life and their ancestral land rights over Etosha National Park, there is little indication that a satisfactory legal resolution is happening soon.

As in many instances elsewhere, the indigenous defendants despair over the 'inaction' and delay that robs them of the opportunity to enjoy in their own lifetime what may eventually be granted to them. Moreover, once a court

8 Part of this time regime is the streamlining of diverse interests into 'stakeholder groups' who may be allowed to air their views at 'hearings' at particular points in time. State officials tend to present themselves in this context as indispensable mediators in the process while, at times, masking their own interests. 
ruling has been made, there is very little room for renegotiation, for a court ruling brings a sense of finality and 'eternity' in that it informs (at least in common law) any possible future claims. The politics of temporal frames works at several layers with politicians, bureaucrats, NGO or civil society representatives each having their own deadlines and cycles that may or may not coincide with those of the other parties involved. When conflicts with the government arise the general claims to promote and maintain the welfare particularly of marginalized parts of the population do not translate into a prioritizing of the temporal frames of marginalized groups such as the Haillom San. Their claims are subsumed under the dominant temporal frames.

\section{The Positioning in Temporal Frames}

Having sketched questions relating to the recognition, standardization and politics of temporal framings in the establishment of national parks we want to end by making some suggestions in terms of an outlook for future research and new theoretical ideas. It seems important to point out the diversity of time frames (and of practices of framing) that are to be found in this domain, not only across but also within countries.

The first task for researchers is to detect the largely implicit temporal frames that are being employed. The next task is to analyse who uses these temporal frames and who is guided by them without being aware of them. In this process, it is also important to note that having, or accepting, a particular time frame does not predetermine how agents position themselves (and others) in it. Even when a certain way of temporal framing becomes dominant and is standardized, there are open questions over what point in time one has reached within that accepted time frame. ${ }^{9}$ Both in Germany and Namibia, it is commonplace

$9 \quad$ As Alfred Gell (1992) outlined, this is a well-established problem in the anthropology of time. The collection of calendars, or what Gell (1992: 151) calls "A-series time" has been a longstanding interest in the ethnography of time. What seasonal calendars do people use to move around in their environment or to make specific uses of their environment? What ritual calendars do they consult to organize their social lives or deal with conflicts and crises? However, recording the calendars is one thing, positioning yourself with regard to any given calendar (or any other temporal frame) is yet another. Gell points out that many of the misunderstandings between local informants and researchers can be traced back to this distinction. While researchers try to elicit calendars as a temporal map with which to navigate an unknown territory, in their responses many informants for whom the calendar is a known territory grapple with the question of positioning themselves and others within these frames. In other words, the answers they give do not refer to the point in the calendar when they should plant, harvest, hunt, or do nothing. Rather, 
for people to believe that 'the government' implements its plans irrespective of what locals think, even at a point in time when the processes are still open. Conversely, occasional resistance is exhibited long after the window of opportunity for influencing political processes has closed.

Positioning oneself in a time frame in the realm of nature conservation is often expressed historically in terms of initiators, early adopters and late adopters. The history of many nature reserves in southern Africa is one in which expatriate nature conservationists (occasionally former big game hunters) are seen as the initiators (see Carruthers 1995), government agencies, the military and NGO s as the early adopters, and the local community as the latecomers. The personnel in German national parks seem to assume that locals will continue to resist if they see their rights curtailed, but that opposition will peter out over time. In Namibia, the opposite assumption is more likely to be heard, namely that with growing population pressure and growing demands on land there will be more disputes about reserving land for nature reserves. In both cases, further research is needed to understand the diversity within each case and to determine both, similarities and differences.

In many instances, the temporal positioning is also hierarchical, namely based on ideas of seniority or centrality. In southern Africa, government officials (and expatriate consultants) frequently engage in patronizing discourses with the local people, whom they look upon as being of an inferior status. For example, when addressing the Khwe San residents at an annual general meeting of their community-based organization, a representative of the Namibian ministry in charge of running the Bwabwata National Park said that, "We [the ministry] are the parents in the Park, and you [Khwe] are the children. You do what your parents are telling you to do."10 Patronizing discourses between state authorities and residents also have a track record in Germany (see Radkau 1996), where they are typically framed in terms of the centrality and importance of central state administrators (and scientists) and the backwardness or ignorance of local village residents.

Analytically and practically, we see the need not only to elicit variation (and agreement) on how to frame the future of national parks but also, and maybe more importantly, on how various participants in the process position themselves and one another in these temporal frames. Also, there is a growing awareness that humans are not the only ones determining temporal frames. With climate change and other influences by non-human agents on

for the practitioner, the relevant question is whether one had reached that point in the (idealized) sequence of events for carrying out certain activities. 
established timeframes, it may become necessary to alter the existing temporal framings for national parks. This includes the definition of what is an 'appropriate' or 'native' plant or what may be necessary adaptations and alterations of frames that were adopted when a park was first conceptualized but that may require revision as it develops. Although some human groups occasionally claim to speak for certain species of animals in a park, in all cases the temporal framings seem to be rather anthropocentric.

\section{Acknowledgements}

We would like to acknowledge the support and permission we received for carrying out field research in Namibia over the past years and in Germany (in the Eifel and Black Forest National Parks in 2020). We are also grateful to the editors and to the anonymous reviewers whose comments have helped us to sharpen our argument.

\section{References}

Abbott, A. D. 2016. Processual sociology. Chicago: University of Chicago Press.

Boden, G. 2009. "The Khwe and West Caprivi before Namibian independence: Matters of land, labour, power and alliance." Journal of Namibian Studies, 5: 27-71.

Carruthers, J. 1995. The Kruger National Park: A social and political history. Pietermaritzburg: University of Natal Press.

Comaroff, J. and J. Comaroff. 2011. Theory from the South: Or, how Euro-America is evolving toward Africa. Florence: Taylor \& Francis.

Cronon, W. 1996. "The trouble with wilderness; or: Getting back to the wrong nature." In Uncommon ground: Rethinking the human place in nature, edited by W. Cronon, 69-9o. New York: W. W. Norton.

de la Bat, B. 1982. "Etosha, 75 years." South West African Annual, 38: 11-26.

Dieckmann, U. 2007. Hai//om in the Etosha Region: A history of colonial settlement, ethnicity and nature conservation. Basel: Basler Afrika-Bilbliographien.

Gell, A. 1992. The anthropology of time. Cultural constructions of temporal maps and images. Oxford: Berg.

Jones, B. T. B. and U. Dieckmann. 2014. "Bwabwata National Park." In Scraping the pot: San in Namibia two decades after independence, edited by U. Dieckmann, M. Thiem, E. Dirkx and J. Hays, 173-231. Windhoek: Legal Assistance Centre (Namibia)/Desert Research Foundation of Namibia.

Mbembe, J.-A. 2017. Critique of black reason. Durham: Duke University Press. 
Menges, W. 2015. "Haillom sue for rights over Etosha". The Namibian Newspaper, 19 October. https://www.namibian.com.na/index.php?page=archive-read\&id=143198. NACSO. 2015. Community conservation in Namibia: A review of communal conservancies community forests and other CBNRM initiatives. Windhoek: NACso. http:// www.nacso.org.na/sites/default/files/2014-15_SoCC-Report.pdf.

Paksi, A. and A. Pyhälä. 2018. "Socio-economic impacts of a national park on local indigenous livelihoods. The case of the Bwabwata National Park in Namibia." Senri Ethnological Studies, 99: 197-214.

Radkau, J. 1996. "Wood and forestry in German history. In quest of an environmental approach." Environment and History, 2, 1: 63-76.

Sapignoli, M. 2018. Hunting justice. Displacement, law, and activism in the Kalahari. Cambridge: Cambridge University Press.

Suzman, J. 2001. An assessment of the status of the San in Namibia. (Report no. 4 of 5). Windhoek: Legal Assistance Centre (LAC).

Wild Europe. 2013. A working definition of wilderness and wild areas. https://www .wildeurope.org/wp-content/uploads/2020/o7/WEI-defs-200720-1.pdf.

Zips-Mairitsch, M. 2013. Lost lands? (Land) rights of the San in Botswana and the legal concept of indigeneity in Africa. Zürich: LIT-Verlag. 